THE NOVEL IN ENGLISH AN INTRODUCTION 
Macmillan International College Edition

Titles of related interest:

General Editor: Professor A. N. Jeffares, University of Stirling

G. J. Watson: Drama: An Introduction

Charles Barber: Poetry in English: An Introduction

Richard Taylor: Understanding the Elements of Literature

M. M. Badawi: Background to Shakespeare

Bruce King: The New English Literatures

Bruce King: West Indian Literature

S. H. Burton and C. J. H. Chacksfield: African Poetry in English 


\section{THE NOVEL IN ENGLISH}

\section{AN INTRODUCTION}

\section{Ian Milligan}

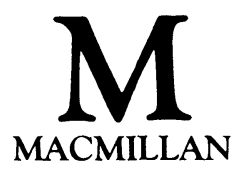


All rights reserved. No reproduction, copy or transmission of this publication may be made without written permission.

No paragraph of this publication may be reproduced, copied or transmitted save with written permission or in accordance with the provisions of the Copyright Act 1956 (as amended).

Any person who does any unauthorised act in relation to this publication may be liable to criminal prosecution and civil claims for damages.

First published 1983

Reprinted 1985

Published by

Higher and Further Education Division

MACMILLAN PUBLISHERS LTD

Houndmills, Basingstoke, Hampshire RG21 2XS

and London

Companies and representatives

throughout the world

ISBN 978-0-333-32439-4

ISBN 978-1-349-17117-0 (eBook)

DOI 10.1007/978-1-349-17117-0 


\section{Contents}

Foreword vii

Preface ix

Acknowledgements $\quad \mathrm{x}$

1 First Thoughts on Novel-Reading 1

Why read novels? 1

What novels should we read? $\quad 8$

$\begin{array}{lr}\text { The widening circle } & 10\end{array}$

2 Some Elements of Fiction 14

$\begin{array}{ll}\text { What is a novel? } & 14\end{array}$

The novel as history $\quad 17$

The novel and the fable $\quad 21$

The novel and the character 25

3 The Language of the Novel 30

Beginnings $\quad 30$

New voices $\quad 47$

4 How the Story Gets Told 54

Episode and plot $\quad 54$

Point of view 57

'First person' narrative $\quad 63$

The author's 'tone of voice' 66

5 The Novel and the Story 72

Pride and Prejudice: narrative as discovery $\quad 74$

The Great Gatsby: discovery and the patterns of symbolism $\quad 89$

6 The English Novel: Makers and Masters 99

7 Pattern and Design in the Structure of the Novel: A Study of Tess of the d'Urbervilles 
vi Contents

8 The Novel in English: Some Forms of Modern Fiction 132

9 Conclusion: Some Basic Concepts Reviewed 143

$\begin{array}{ll}\text { Plot } & 143\end{array}$

Realism and fantasy $\quad 145$

$\begin{array}{ll}\text { Narrative } & 146\end{array}$

$\begin{array}{ll}\text { Action } & 148\end{array}$

$\begin{array}{lr}\text { Character } & 149\end{array}$

$\begin{array}{ll}\text { Setting } & 157\end{array}$

Symbolism and imagery $\quad 158$

$\begin{array}{ll}\text { Language and style } & 164\end{array}$

$\begin{array}{lr}\text { References } & 166\end{array}$

Bibliography 170

$\begin{array}{ll}\text { Index } & 171\end{array}$ 


\section{Foreword}

There are so many novels, and they are so varied in subject, style and achievement. They bear witness to the curiosity of mankind about itself, they show us how writers see men and women in their societies, and they often demonstrate men and women coming to terms with society in the process of growing up, of learning, of making crucial judgements, of taking decisions, either carrying out actions themselves or reacting to the thoughts, the emotions, the behaviour of others. And behind all this analysis and action, this dialogue and description, this creation which reaches into realism or the infinities of imagination, or mingles these extremes, there is, almost inevitably, the human desire to tell a story, a story about people. Once upon a time... He spoke to her, and she replied to him ... The door opened and the golden light irradiated the room where...

The European novel, the English novel, the American novel have different nuances, but their general achievement has been the creation of a world, a fictional world where fact and fancy have intermingled, a populous world in which we find the living characters the novelists have created: men and women who have a vibrant, reverberating life, who have compelled the attention, evoked the sympathy, deserved the repulsion, stimulated the thoughts of readers - over centuries in many cases. Robinson Crusoe discovers the footprint on the sand; Emma is rude to Miss Bates; Catherine Earnshaw says 'I am Heathcliff'; Oliver Twist asks for more; Long John Silver breaks out into 'Fifteen men on the dead man's chest'; Lord Jim repeatedly exclaims 'Nothing can touch me'; Paul Morel feels 'dreary and hopeless' between Miriam and Mrs Morel; and Stephen Daedalus tells his friend Cranly 'I will not serve that in which I no longer believe'.

Novelists continually add to the richness of our human experience; they bring before us new topics, new characters, new attitudes. $\mathrm{Mr}$ Milligan in this Introduction to the novel in English rightly includes 


\section{Foreword}

discussion of novelists who do not come from Britain or America, but are writing in English about their own people - their problems and their pleasures - and adding to our common stock of enjoyment and experience in so doing. Achebe's Okonkwo, Robertson Davies's Monica Gall, Janet Frame's Vera Glace, V. S. Naipaul's Mr Biswas, R. K. Narayan's Krishna the Malgudi schoolteacher, or Patrick White's Mrs Flack join the characters created by earlier novelists. They become inhabitants of our village, the village of the English-speaking, Englishreading world. Their creators have often been engaged in discovering the nature of national identities: not only have they brought into the novel a lively, fresh, idiosyncratic use of the English language as it has developed in their countries, but they have interpreted attitudes, moral standards and values, all of which may differ from those of their readers, and consequently they often have a powerful, shaping role in influencing ideas both inside and outside their own countries.

Influential novels undoubtedly have always been; but unless reading them is pleasurable, unless they are, ultimately, enjoyable, their survival value is decidedly dubious. Mr Milligan stresses their emotional effect. No novel, he says, has the right to be dull. And no reader should be passive either! In this book Mr Milligan indicates stimulating ways in which readers can increase the pleasure they experience in reading fiction, by responding to the rewarding challenges each novel presents. To do this is to develop an understanding and an appreciation of different kinds of novels written at different times and in different places. It requires us to read critically, and this both deepens our sensibility and increases our capacity for informed and balanced judgement, for engaging fully those intellectual and emotional responses that contribute our enjoyment. 


\section{Preface}

There are few novices in the art of novel-reading; even in an age of television reading begins early, and most interested readers of novels have a wealth of experience to draw on if they decide to take a closer look at how novels are written. This book has been written to encourage students to deepen their experience of reading by paying close attention to the language of the novel. It goes beyond 'practical criticism' by suggesting ways of understanding the structure and design of the novel as a whole. It has been written in the belief that close attention to the text not only increases understanding but enhances the pleasure which readers will find in it.

Reading in depth is a valuable skill, but it may lead to an undesirable narrowing of the range of the reader's interest. The novel in English has been enriched by the contributions of novelists in India, in Africa, in America, in Australasia, in the Caribbean and in India. Students of literature in Britain are often too little aware of these writers, while students elsewhere may sometimes fail to remember the links between novels in English written in their own countries and the historical tradition of which they form a part.

No one book can fulfil all of these objectives, but I am deeply grateful to Professor A. N. Jeffares for encouraging me to write this one, which claims to be no more than an introduction to the novel in English. I wish to thank Miss M. W. Prentice and Miss E. McLellan for their patient and cheerful help in producing the typescript. On this occasion, as on others, my wife's good sense and clear judgment have saved me from some errors: for those that remain the responsibility is mine.

University of Stirling.

Ian Milligan 


\section{Acknowledgements}

The author and publishers wish to thank the following who have kindly given permission for the use of copyright material: The Bodley Head Ltd for an extract from The Great Gatsby by F. Scott Fitzgerald in The Bodley Head Scott Fitzgerald, and with Random House, Inc., for an extract from Ulysses by James Joyce; William Heinemann Ltd for an extract from Things Fall Apart by Chinua Achebe; Heinemann Educational Books Ltd and Houghton Mifflin Company for an extract from The Beautyful Ones Are Not Yet Born by Ayi Kwei Armah, Copyright $\odot 1968$ by Ayi Kwei Armah; David Higham Associates Ltd on behalf of R. K. Narayan for an extract from The English Teacher; Laurence Pollinger Ltd on behalf of Graham Greene, and Viking Penguin Inc., for an extract from The End of the Affair, Copyright () 1951, 1974 and 1979 by Graham Greene; Samuel Selvon for an extract from The Lonely Londoners; The Society of Authors as the Literary Representatives of the Estate of James Joyce and Viking Penguin Inc., for an extract from Finnigan's Wake, Copyright 1939 by James Joyce and renewed 1967 by George and Lucia Joyce.

Every effort has been made to trace all the copyright holders but if any have been inadvertently overlooked the publishers will be pleased to make the necessary arrangements at the first opportunity. 